\title{
The Effect of Organic and Inorganic Fertilizers on Growth and Yield of Bread Wheat (Triticum aestivum L.)
}

\author{
Nuru Seid Tehulie* and Tarikua Shumi Tola \\ Department of Plant Science, College of Agriculture, Mekdela Amba University, Ethiopia \\ *Corresponding author: Nuru Seid Tehulie, Department of Plant Science, College of Agriculture, Mekdela Amba University, Ethiopia
}

\begin{abstract}
Wheat (Triticum aestivum L.) is a dominant cereal crop of north-western zone of India and it is second most common crop of the country. It is also one of the major staple crops in many the country in terms of both production and consumption. Soil fertility maintenance requires a balanced application of inorganic and organic nutrient sources. Sustainable agricultural productivity might be achieved through a wise use of integrated nutrient management. Integrated use of chemical and organic fertilizer on yield and yield components of wheat is very crucial for assurance of food security. Integrated nutrient supply/management (INS) aims at maintenance or adjustment of soil fertility and plant nutrient supply to an optimum level for sustaining the desired crop productivity through optimization of benefit from all possible sources of plant nutrients in an integrated manner which includes; Maintain or enhance soil productivity through a balanced use of fertilizers combined with organic and biological sources of plant nutrients. Improve the stock of plant nutrients in the soils, and the efficiency of plant nutrients, thus, limiting losses to the environment. The integrated nutrient management system (INMS), nevertheless, remains the maintenance and possible improvement of soil fertility for sustained crop productivity on long term-basis and also to reduce inorganic (fertilizer) input cost. Different kinds of organic materials such as FYM, animal manures, green manures, crop residues, composts, and industrial wastes have been used in wheat systems. The amount and availability of nutrients in organic materials vary widely, which makes interpretation of the value of nutrients supplied. The literatures lines of research in wheat are presented in an elaborative method were reviewed in this paper.
\end{abstract}

Keywords: Bio-fertilizer; Integrated nutrient management; organic fertilizer; Inorganic fertilizer

\section{Introduction}

Wheat (Triticum aestivum L.) is the most important cereal crop in the World and stands next to rice in India. Production of wheat in Ethiopia ranks fourth after Teff, Maize and Sorghum, and third in total production CSA [1]. Increased agricultural productivity occurred largely due to the development of high-yielding cultivars and increased fertilizer use. The food crises all over the world and increasing population pressure demand urgent need to increase the quantity and improve the quality of grains. To meet the demand yield increase per unit area can be achieved by proper and balanced dose of fertilization, irrigation, time of sowing, use of quality seed etc. The calcareous nature of soils, high $\mathrm{pH}$, low organic matter, salt stress, continual drought, high bicarbonate content in irrigation water and imbalanced application of fertilizers micronutrient deficiency, especially Zn, at all Khan et al. [15] could affect wheat yield and quality.

Moreover, integrated Nutrient Management (INM) promotes the use of balanced and judicious use of chemical fertilizers in conjunction with manures like compost, farmyard manure, vermicomposting, green manures and use of fertilizers fortified with micro-nutrients, use of bio-fertilizers that can supplement a part of NPK fertilizers Herbert [2] as referred to by Habtamu Deribe et al. [3] Judicious use of FYM with chemical fertilizers improves soil physical, chemical and biological properties and improves the crop productivity Sharma et al. [4]. Application of organic manures may also improve availability of native nutrients in soil as well as the efficiency of applied fertilizers Sawrup 2010). Organic materials, 
such as green manure (GM), crop residues and animal manure, and their continuous use have a strong influence on soil productivity and agronomic efficiency of wheat crop and $\mathrm{N}$ dynamics in the soilplant system Schmidt 2004). Among different sources of organic manures, vermi-compost is most important source and used since long as a nutrients supplement to crop production. Use of micronutrients improves the quality and quantity of wheat. Rafique et al. [5] reported that in Pakistan Zn requirement for wheat is low (i.e., $2.0 \mathrm{~kg} \mathrm{Zn} / \mathrm{ha}$ ) and $\mathrm{Zn}$ use enhances wheat productivity in a highly cost effective manner. $\mathrm{Zn}$ content in mature wheat grain is a good indicator of soil $\mathrm{Zn}$ availability status to plants.

\section{Objective}

To review the effect of integrated nutrient management on growth and yield of wheat.

\section{Literature Review}

Sustainable agricultural systems wheat requires management of soil organic matter, crop rotation, use of organic inputs such as animal manures, crop residues, green manures, sewage sludge, and food industry wastes. The basic concept underlying the integrated nutrient management for wheat remains the maintenance and possible improvement of soil fertility for sustained wheat productivity on long-term basis and also reduction of fertilizer inputs. The amount and availability of nutrients in organic materials vary widely, which makes interpretation of the value of nutrients supplied by these materials a difficult task Yadavet al. [6].In the coming decades, a major issue in designing sustainable agricultural systems will be the management of soil organic matter and the rational Use of organic inputs such as animal manures, crop residues, green manures, sewage sludge, and food industry wastes. The basic concept underlying the integrated nutrient management remains the maintenance and possible improvement of soil fertility for sustained crop productivity on long-term basis and also reduction of fertilizer inputs. In South Asia, use of organics along with fertilizers is less popular in wheat than in summer season crops like rice and maize because during winter when wheat is in the fields, mineralization of organic materials is slow. However, in wheat-based cropping systems, substantial residual effect of organic materials applied to preceding summer season crops can be observed in wheat. Different kinds of organic materials such as FYM, animal manures, green manures, crop residues, composts, and industrial wastes have been used in wheat systems. The amount and availability of nutrients in organic materials vary widely, which makes interpretation of the value of nutrients supplied by these materials a difficult task Habtamu Deribe et al. [3].

\section{The Effect of Farmyard Manure on Growth and Yield Of Wheat}

FYM is the most commonly used organic manure in wheatbased cropping systems in South Asia. It is generally applied to rice or maize grown in summer, but it leaves considerable residual effect in the following crop of wheat in winter. Some researchers have also attempted to find the value of FYM when it is directly applied to wheat. Similar observations were recorded by Khan et al. [7] applied $25 \%$ of the recommended fertilizer $\mathrm{N}$ to wheat through FYM and recorded yield of wheat equivalent to that produced by $100 \%$ inorganic fertilizers. In Bangladesh Bodruzzamanet al. [1] observed that application of $10 \mathrm{t} \mathrm{FYM/ha}$ along with75\% of the local fertilizer recommendation produced grain yield of wheat equivalent to $100 \%$ of the inorganic fertilizer treatment $(100 \mathrm{~kg} \mathrm{~N} /$ ha, $26 \mathrm{~kg} \mathrm{P} / \mathrm{ha}, 33 \mathrm{~kg} \mathrm{~K} / \mathrm{ha}$ ). The application of $10 \mathrm{t} / \mathrm{ha}$ FYM along with $100 \%$ local recommendation of NPK (120 kg N / ha, $26 \mathrm{~kg} \mathrm{P} \mathrm{/ha}$ and $25 \mathrm{~kg} \mathrm{~K} / \mathrm{ha}$ ) produced wheat grain yield as high as produced by $150 \%$ NPK. The application of 10 t/ha FYM along with 100\% NPK (local recommendation) to maize, followed by $100 \%$ NPK to wheat recorded the highest yield of both maize and wheat in a maizewheat sequence. The application of FYM on a calcareous soil could substitute $50 \%$ of the $P$ requirement of rice and left a residual effect equivalent of $13.1 \mathrm{~kg} \mathrm{P} /$ ha in the following crop of wheat. The grain yield of wheat grown after rice on soils amended with FYM at $12 \mathrm{t} /$ ha along with $80 \mathrm{~kg} \mathrm{~N} /$ ha and $17.5 \mathrm{~kg} \mathrm{P} /$ ha was significantly higher than that obtained in plots where only $120 \mathrm{~kg} \mathrm{~N} /$ ha Bodruzzaman et al. [8].

\section{Effect of Poultry Manure on Growth and Yield Wheat}

Rate of $\mathrm{N}$ mineralization from poultry manure is faster than from FYM because it contains high amount of uric acid and urea substances which readily release NH4-N. In a laboratory study, about $45 \%$ of total in poultry manure was mineralized in 4 weeks as compared to $12 \%$ from FYM. Bijay-Singhet al. [9] showed that poultry manure-N was not only as efficient as urea-Nin increasing yield and $\mathrm{N}$ uptake of rice but also showed significant residual effect equivalent $40 \mathrm{~kg} \mathrm{~N} / \mathrm{ha}$ in wheat. Application of poultry manure was also found to leave a positive impact on soil health and sustainability of wheat-soybean system. In experiments conducted by Shah et al. [10] at Peshawar (Pakistan), maximum grain yield of wheat was recorded from the treatment in which $25 \% \mathrm{~N}$ was applied from poultry manure and $75 \%$ from fertilizer. In Bangladesh, Bodruzzaman et al. [8] recorded significantly higher wheat yield by applying poultry manure at $10 \mathrm{t} /$ ha along with $75 \%$ of the recommended NPK dose over the $100 \%$ NPK treatment. A residual effect of poultry manure equivalent to $30 \mathrm{~kg} \mathrm{~N} /$ ha and 13 $\mathrm{kg} \mathrm{P} /$ ha was observed in the following wheat.

\section{Effect of Green Manure on Growth and Yield of Wheat}

Green manures applied directly to wheat are generally the leaves of Leucaena left as mulch or incorporated into the field. Application of Leucaenaleucocephala increased wheat yield by 
11.7\%. About 3.14 t/ha green Leucaena leaves containing 3\% $\mathrm{N}$ on dry weight basis when incorporated into the soil 15 days before planting increased wheat grain yield at par with $100 \mathrm{~kg}$ $\mathrm{N} /$ ha applied through urea. In a maize-wheat cropping system, Leucaena green leaf manure containing 3.83-4.25\%Nwas applied to provide $60 \mathrm{~kg} \mathrm{~N} /$ ha before planting of wheat. In South Asia, several workers have observed significant residual effect of green manure incorporated before planting summer season crops on the productivity of wheat grown in winter Shehataet al. [11]. In a maize-wheat rotation when different green manures were applied to maize, wheat was benefitted due to the residual effect of summer legumes to the extent of $18-23 \mathrm{~kg} \mathrm{~N} / \mathrm{ha}$ after cowpea and green gram and $27 \mathrm{~kg} \mathrm{~N} /$ ha after Sesbania Beheraet al. [12].

\section{The Effect of Crop Residues on Growth and Yield Wheat}

The long-term effects of crop residue incorporation are generally expected to be beneficial; the short-term effects are often unpredictable. Nitrogen-15 recovery by wheat was the highest (41\%) when rice straw was removed or burned and the lowest (30.4\%) when 30 of the $120 \mathrm{~kg} \mathrm{~N} /$ ha was applied at the time of straw incorporation at 20 days before planting of wheat Vermaet al. [13]. Incorporated rice straw ( $5 \mathrm{t} / \mathrm{ha}$ dry weight) 30 days before the planting of wheat and could record significantly lower grain yield than the removal or burning of straw in the first 2 years. The treatment with no rice straw incorporation and application of recommended doses of fertilizer $(120 \mathrm{~kg} \mathrm{~N} / \mathrm{ha}, 26 \mathrm{kgP} / \mathrm{ha}$, and 50 $\mathrm{kg} \mathrm{K} / \mathrm{ha}$ ) produced the highest yield of wheat. Treatments with the incorporation of rice straw at $5 \mathrm{t} /$ ha with additional $60 \mathrm{~kg} \mathrm{~N} / \mathrm{ha}$ produced grain yield similar to that in the treatment with no straw incorporation. Although in some studies the negative effects of residue incorporation in a rice-wheat cropping system diminished after a few initial years Dhiman et al. [14]. As immobilization of $\mathrm{N}$ is temporary, and $\mathrm{N}$ can be released during the cropping season through mineralization, the optimal distribution of fertilizer $\mathrm{N}$ during the growing season to synchronize $\mathrm{N}$ supply with $\mathrm{N}$ need by the crop can differ when crop residue is incorporated Yadav et al. [6].

\section{Composts}

\section{The effect of composts on growth and yield of wheat}

Composting of organic manures increases the nutrient content, reduces the bulk to be handled per unit of nutrients, and offers a potential for the utilization of low solubility materials such as phosphate rocks Mostafa et al. [15]. P-enriched phosphor compost from crop residues, animal feed wastes, grasses, weeds, tree leaves cattle dung, biogas slurry, and Missouri rock phosphate the wheat yield. Phosphorus compost was found to be comparable to superphosphate in increasing grain yield of wheat Mostafa et al. [15]. The compost from paddy straw using urea and Missouri rock phosphate for $\mathrm{N}$ and $\mathrm{P}$ enrichment is important. Inorganic $\mathrm{N}$ was partly conserved in the compost by the addition of pyrite. Compost containing about $1.6 \%$ total $\mathrm{N}$ and $3.3 \%$ total $\mathrm{P}$ was found to be a good source of $\mathrm{P}$ for a wheat crop and could supply significant amount of $\mathrm{N}$ to the plants Mostafa et al. [15].

\section{The effect of cereal-legume intercropping on growth and yield wheat}

Inclusion of legumes intercropping or rotation offers considerable benefits because of their ability to fix atmospheric nitrogen biologically $\mathrm{m}$ symbiosis With Rhizobium. There are two main types of mechanisms postulated for the beneficial effects of legumes m multiple cropping systems Anonymous [16] through Immediate transfer, which nitrogen travels from the legume directly to the associated crop, and Behera et al. [12] through residual effects Which nitrogen fixed by the legume is available to an associated sequentially cropped non-legume after senescence of the legume and decomposition of Its organic residue. Although some research workers have reported evidence of direct transfer of $\mathrm{N}$ maize/ cowpea intercrop it is believed that $\mathrm{N}$ benefits of these systems may accrue more to subsequent crops after root and nodule senescence and decomposition of fallen leaves. It is generally known that soil conditions, such as $\mathrm{P}, \mathrm{Ca}$ and Mo deficlenc1es, $\mathrm{Al}$ and $\mathrm{Mn}$ tox1c1tles, and drought stress are limiting factors for N2 fixation Habtamu Deribe et al. [3].

\section{The effect of Bio Fertilizers on growth and yield of wheat}

The quantity of organic matter in the soil is a major soil quality indicator. To achieve higher grain yield, we should apply chemical, bio and organic fertilizers. For sustainability, it is important to incorporate bio organisms and organic matters into the soil Koopmans et al. [17].To improve soil quality we should treat our organic matter like a bank account. For sustainability, it is important to deposit in the account active bio-fertilizers along with organic matter in the soil on a regular basis, thereby, building cultural fertility. Poulton [18] Summarized that long term experiments are essential in determining the factors affecting soil fertility and sustainable production. The use of non-symbiotic nitrogen fixer, Azotobactorspp, as bio-inoculants is known to benefit a wide variety of crops due to its properties like nitrogen fixation, secretion of growth promoting substances, vitamins and antifungal metabolites and phosphate solubilisation Mishustin et al. [19]. Bio fertilizers are considered as the most important factor in reducing the application of chemical nitrogen fertilizers and minimizing the induced environmental pollution such as those resulted from nitrogen losses (volatilized NH4 and/or leaching NO3. Hence, increasing attentions is being paid to biological N2 fixation meet the $\mathrm{N}$ requirements Canbolatet al. [5] and improve the soil fertility status to sustain crop yield Mostafaet al. [15]. 


\section{The effect of chemical fertilizers on growth and yield of wheat}

For late-planted wheat, application of all the fertilizers at planting is recommended. Potassium should be applied as per soil analysis (FAO, 2004). Increase in fertilizer use mirrors the gains in productivity, but to maintain production in the years to come, efficient management of nutrients supplied by fertilizers will assume more importance than the quantity of nutrients applied to wheat. Lower rates, split application, banding) of inorganic fertilizers on the infertile kaolintic and oxide Solis are needed to sustain high crop yield and maintain an optimum balance of nutrient in agro ecosystems(FAO, 2004).

\section{The effect of nitrogen fertilizer on growth and yield of wheat}

Ayoub et al. [20] reported the increase in yield and yield parameters of wheat with the increase in successive $\mathrm{N}$ levels from $0,60,120$ and $180 \mathrm{~kg} \mathrm{~N}$ ha -1 . Increase in grain yield was from 27 to $81 \%$ at $\mathrm{N}$ rates of 120 and $180 \mathrm{~kg}$ ha -1 , respectively. Gelato et al. [21] reported that grain and biomass yield and most grain yield components increased by increasing $\mathrm{N}$ rate. Frederick et al. [22] reported the influence of $\mathrm{N}$ rates on yield and yield associated traits of wheat on irrigated fields. They reported significant increase in grain yield with $135 \mathrm{~kg} \mathrm{~N}$ ha -1 . Singh et al. [23] reported that the application of $\mathrm{N}$ recorded more grain and straw yield of and wheat over control. Rajender et al. [23] reported that there was a linear rise in grain yield and straw yield with every additive dose of NPK fertilizer up to 120-60-40 kg NPK/ha.

Among forms of $\mathrm{N}$, nitrate is the most susceptible to leaching, ammonium the least, while urea is moderately susceptible. Ammonium and urea are more susceptible to volatilization loss of $\mathrm{N}$ as ammonia than the fertilizer materials containing nitrate. Urea is the major source of fertilizer N for wheat systems in the South Asia. Small quantities of calcium ammonium nitrate (CAN), ammonium chloride and ammonium sulphate are also available to farmers growing wheat. One of the major reasons for low $\mathrm{N}$ use efficiency in wheat is inefficient splitting of $\mathrm{N}$ doses. Fertilizer $\mathrm{N}$ needs to be applied at growth stages when $\mathrm{N}$ demand of the crop is the highest. Time of fertilizer $\mathrm{N}$ application in irrigated wheat depends not only upon $\mathrm{N}$ demand but also on the specific irrigation schedule that is followed. As efficient $\mathrm{N}$ use is central to eco-efficiency in agriculture, it is important to work out fertilizer $\mathrm{N}$ doses that will not only produce high yields of wheat per unit area but also result in minimal environmental impacts while remaining economically attractive to farmers. Beri et al. [24] observed greater decline in wheat yield at a low rate of $\mathrm{N}$ application $(0.5 \mathrm{t} /$ ha decline at 60 $\mathrm{kg} \mathrm{N} / \mathrm{ha}$ ) than at a high rate of $\mathrm{N}$ application $(0.08 \mathrm{t} / \mathrm{ha}$ decline at $180 \mathrm{~kg} \mathrm{~N} / \mathrm{ha}$ ).

\section{The effect of phosphorus fertilizer on growth and yield wheat}

Presently, DAP is the major source of P used in wheat in South Asia; it accounts for nearly $65 \%$ of the P used in India. The other sources of $\mathrm{P}$ are SSP, ammonium nitro phosphates (ANP), and compound fertilizers. The efficiency of a P source varies depending upon proportion of water soluble $\mathrm{P}$ and soil properties such as $\mathrm{pH}$.In neutral to alkaline soils; materials containing water-soluble $\mathrm{P}$ have proved more efficient than materials containing citric acid-soluble or citric acid-insoluble P Bijay-Singhet al. [9]. Mono ammonium phosphate and DAP the two fully water-soluble P sources-were found to be equally efficient in supplying P to wheat. In South Asia, fertilizer P is generally broadcasted on soil surface followed by soil incorporation before planting of wheat. It results in conversion of soluble $\mathrm{P}$ to insoluble forms and thus reduces its use efficiency. Fixation of broadcasted $\mathrm{P}$ is greater than when fertilizer is applied in bands because of reduced contact with soil Bijay-Singh et al. [9].

\section{The effect of potassium fertilizer on growth and yield wheat}

Muriate of potash $(\mathrm{KCl})$ is the major fertilizer K source for wheat because of its low cost and high $\mathrm{K}$ analysis. At planting of wheat, fertilizer $\mathrm{K}$ is generally applied by drilling, placement or broadcast followed by incorporation Bijay-Singh et al. [9]. Application of full dose of $\mathrm{K}$ at planting of wheat is the commonly followed practice in South Asian wheat growing regions. As sustained supply of $\mathrm{K}$ is necessary up to heading stage, split application of fertilizer potassium in wheat in coarse-textured soils may give higher $\mathrm{K}$ use efficiency than its single application due to reduction in leaching losses and luxury consumption of $\mathrm{K}$ have cited several references showing a distinct benefit of applying fertilizer $\mathrm{K}$ in split doses. In a sandy loam soil, obtained a wheat yield advantage of 440-490 kg grain/ ha by split application of fertilizer K over single application Bijay-Singh et al. [9].

\section{The effect of micronutrients on growth and yield wheat}

For high yields, Mn and Zn may be in short supply in neutral to alkaline soils and $\mathrm{Cu}$ on sandy soils. $\mathrm{Zn}$ deficiency is generally a problem in coarse-textured soils under intensive cropping. Here, an application of zinc sulphate of $62.5 \mathrm{~kg} / \mathrm{ha}$ once every 2-3 years is suggested Shehata et al. [11]. Generally, 2-3 sprays at 15-day intervals may be needed. In Mn-deficient soils, foliar spray with 0.5- percent manganese sulphate solution 2-4 days before the first irrigation and again 2-3 times at weekly intervals can be done on sunny days. However, microelements such as $\mathrm{Fe}, \mathrm{Zn}, \mathrm{Mn}$ and $\mathrm{Cu}$ are also added to foliar fertilizers used throughout the world as effective measure to compensate their deficiency. This has special importance in arid and semi-arid regions where osmotic pressure promotes the absorption and activity of these elements influenced by the plant behavior and the foliar application timing Shehataet al. [11]. 


\section{Effect of integrated nutrient management on growth and} yield wheat

In experiments conducted by Shah et al. [25-29] at Peshawar (Pakistan), maximum grain yield of wheat was recorded from the treatment in which $25 \% \mathrm{~N}$ was applied from poultry manure and 75\% from fertilizer. In Bangladesh, Bodruzzaman et al. [8] recorded significantly higher wheat yield by applying poultry manure at 10 t/ha along with $75 \%$ of the recommended NPK dose over the $100 \%$ NPK treatment. A residual effect of poultry manure equivalent to $30 \mathrm{~kg} \mathrm{~N} / \mathrm{ha}$ and $13 \mathrm{~kg} \mathrm{P} /$ ha was observed in the following wheat [30-37].

In Bangladesh, Bodruzzaman et al. [8] the application of $10 \mathrm{t} / \mathrm{ha}$ FYM along with $100 \%$ local recommendation of NPK (120 kg N /ha, $26 \mathrm{~kg} \mathrm{P} / \mathrm{ha}$ and $25 \mathrm{~kg} \mathrm{~K} / \mathrm{ha}$ ) produced wheat grain yield as high as produced by $150 \%$ NPK. The application of $10 \mathrm{t} /$ ha FYM along with $100 \%$ NPK (local recommendation) to maize, followed by $100 \%$ NPK to wheat recorded the highest yield of both maize and wheat in a maize-wheat sequence. The application of FYM on a calcareous soil could substitute $50 \%$ of the $\mathrm{P}$ requirement of rice and left a residual effect equivalent of $13.1 \mathrm{~kg} \mathrm{P} /$ ha in the following crop of wheat. The grain yield of wheat grown after rice on soils amended with FYM at $12 \mathrm{t} /$ ha along with $80 \mathrm{~kg} \mathrm{~N} /$ ha and $17.5 \mathrm{~kg} \mathrm{P} /$ ha was significantly higher than that obtained in plots where only $120 \mathrm{~kg}$ $\mathrm{N} /$ ha.

\section{Conclusion}

Integrated soil fertility management plays a critical role in both short- term nutrient availability and longer-term maintenance of soil organic matter and sustainability of crop productivity in most smallholder farming systems in the tropics. The many research results showed that the integrated application of organic and inorganic fertilizers improved productivity of yield as well as the fertility status of the soil. Application of Organic manures along with mineral fertilizers led to the greatest increase in NPK and nutrients uptake and wheat yield. These results imply that the integrated use of mineral fertilizers and organic manures represents a sound practice for sustaining NPK reserves in soil and hence enhancing NPK availability in wheat. The application of organic and inorganic fertilizers can increase average wheat yields to 6-7 tons ha-1. Wheat yields are highest when farmyard manure is applied, wheat is grown in rotation and inorganic fertilizers are used to top-up $\mathrm{N}$ availability. Therefore, integrated ways of nutrient management on wheat crop have multipurpose on the improvement of soil fertility and crop productivity in the sustainable manners. It is also important for the improvement of soil chemistry, physics and soil biology before application for a long period of crop season. It is commonly believed that the combination of organic and inorganic fertilizer will increase synchrony, enhancing the efficiency of the fertilizers, and reduce losses by converting inorganic nitrogen (N) into organic forms but also reducing environmental problems that may arise from their use.

\section{References}

1. CSA (2017) Agricultural sample survey: Report on area and production for major crops. Statistical Bulletin 388.Addis Ababa, Ethiopia.)

2. Herbert S (1998) Deptt of Plant and Soil Sci., Univ. of Massachusetts Amherst Crops, Dairy, Livestock News. 3:1.

3. Habtamu Deribe, Tolossa Debele (2016) Review on Integrated Nutrient Management on Growth and Yield of Wheat (Triticum spp) in Ethiopia. Journal of Biology, Agriculture and Healthcare 6(11): 97-104.

4. Sharma A, Behera U (2010) Green leaf manuring with prunings of Leucaenaleucocepala for nitrogen economy and improved productivity of maize (Zea mays) - wheat (Triticumaestivum) cropping system. Nutr Cycl Agroecosyst 86(1): 39-52.

5. Rafique E, Rashid A (2006) Zinc deficiency in rain-fed wheat in Pakistan: magnitude, spatial variability, management and plant. Analysis diagnostic norms Comm. in Soil Sci. \& Plant Analysis, 37(1-2): 181-197.

6. Vasanthi D, Kumaraswamy K (1999) Efficacy of vermicompost to improve soil fertility and cropping system as affected by its residue management and fertility levels. Indian J Agron 45: 1-5.

7. Khan M, Akhtar M, Safdar M, Mahmood S, Ahmed N, et al. (2010) Effect of source and level of potash on yield and quality of potato tubers. Pak J Bot 42(5): 3137-3145.

8. Khan M, Akhtar M, Safdar M, Mahmood S, Ahmed N, et al. (2010) Effect of source and level of potash on yield and quality of potato tubers. Pak J Bot 42(5): 3137-3145.

9. Bijay-Singh, Varinderpal-Singh, Yadvinder-Singh, Thind H, Ajay-Kumar, et al. (2013) Supplementing fertilizer nitrogen application to irrigated wheat at maximum tillering stage using chlorophyll meter and optical sensor Agric Res 2(1): 81-89.

10. MalakoutiM (2008) The effect of micronutrients in ensuring efficient use of macronutrients. Turk J Agric For 32(3):215-220.

11. Shehata S, Abdel-Azem H, Abou El-Yazied A, El-Gizawy A (2010) Interactive effect of mineral nitrogen and biofertilization on the growth, chemical composition and yield of Celeriac plant. Eur J Sci Res 47(2): 248-255.

12. Behera U, Sharma A, Pandey H (2007) Sustaining productivity of wheatsoybean cropping system through integrated nutrient management practices on the Vertisols of central India. Plant Soil 297(1): 185-199.

13. Mishra M (1992) Enrichment of organic manures with fertilizers In: Tandon, H.L.S. (Ed.), Non-Traditional sectors for Fertilizer Use. Fertilizer Development and Consultancy Organization, New Delhi,India 48-60.

14. Khandal D, Bhardwaj N (2000) Effect of vermicompost of typha on two cultivars of wheat. Phytological Res 13 (1): 91-94.

15. Mostafa G, Abo-Baker A (2010) Effect of bio and chemical fertilization on growth of sunflower (Helianthus annuus L.) at south valley area. Asian J Crop Sci. 2: 137-146.

16. Anonymous (2005) Agriculture Statistics of Pakistan Govt. of Pakistan, Ministry of Food, Agric. andLivest, Econ.Wing, Islamabad.

17. Koopmans C, Goldstein W (2001) Soil organic matter budgeting in sustainable farming with applications to southeastern Wisconsin and northern Illinois Bulletin No 7, Michael Fields Agricultural Institute, 39p.

18. Poulton $P$ (1995) The importance of long-term trials in understanding sustainable farming systems: the Roth Amsted experience. Australian Journal of Experimental Agriculture 35(7): 825-834.

19. MishustinE, Shkinova V (1971) Biological nitrogen Fixation of Atmospheric Nitrogen, Macmillan Press Ltd, London. 
20. Ayoub M, Guertin S, Lussier S, Smith D (1994) Timing and level of nitrogen fertilizer effects on spring wheat yield in eastern Canada. Crop Sci 34(3): 748-756.

21. Geleto T, Tanner D, Mamo T, Gebeyehu G (1995) Response of rain fed bread and durum wheat to source level and timing of nitrogen fertilizer on two Ethiopian vertisols. 1. Yield and yield components. Communications in Soil Sci \& Plant Anal 26(11-2):1773-1794.

22. Frederick J, Camberato J (1995) Water and nitrogen effects on winter wheat in the southeastern coastal plain: I. grain yield and kernel traits. Agron J 87(3): 521-526.

23. Singh A, Singh R, Awasthi R (1996) Organic and inorganic sources of fertilizer for sustained productivity in rice (Oryza sativa)-wheat (Triticumaestivum) sequence on humid hilly soils of Sikkim. Indian J Agron 41 (2): 191-194.

24. Beri V, Sidhu B, Bahl G, Bhat A (1995) Nitrogen and phosphorus transformations as affected by crop residue management practices and their influence on crop yield. Soil Use Manage 11(2): 51-54.

25. Shah A, Shah S, Mohammad W, Shafi M, HaqnawazShehzadi S, et al. (2010) Eff Agric 26: 559-563.

26. Atiyeh R, Lee S, Edwards C, Arancon N, Metzger J, et al. (2002) The influence of humic acids derived from earthworms processed organic wastes on plant growth. Bioresour Technol 84(1): 7-14.

27. Desai V, Sabale R, Roundal P (1999) Integrated nutrient management in wheat coiander cropping system. Maharashtra Agric. Univ 24(3): 273275.

28. Dhiman S, Nandal D, Om H (2000) Productivity of rice (Oryza sativa)wheat (TriticumFAO, (2004) Use of phosphate rocks for sustainable agriculture. FAO Fertilizer and Plant Nutrition Bulletin No. 13. Rome.148 $\mathrm{pp}$

29. Kumar A, Yadav D (1995) Use of organic manure and fertilizer in rice (Oryza sativa) Wheat (Triticumaestivum) cropping system for sustain ability. Indian J Agric Sci 65(10): 703-707.

30. Lozek 0, Fecenko J (1998) Effects of the organizational fertilizer vermisol special on the quantity and quality of winter wheat yield. Folia UniversitatisAgriculturaeStetinensis, Agricultura 72: 185-189. 438.

31. Patil V, Bhilare R (2001) Effect of vermicompost prepared from different organic sources on growth and yield of wheat. J Maharashtra Agric Univ 25 (3): 305-306.

32. Rajender K, Anil K, Kumar R, Kumar A (1997) Response of wheat varieties to nitrogen, phosphorus and potassium in sandy loam soils of Haryana. Agric Sci Digest 17: 158-160.

33. Sillanpaa M (1990) Micronutrient assessment at the country level: An international study. The Government of Finland (FINNDA) Food \& Agric. Org of the United Nations, Rome, Italy.

34.(1996) Organic and inorganic sources of fertilizer for sustained productivity in rice (Oryza sativa) - wheat (Triticumaestivum) sequence on humid hilly soils of Sikkim. Indian J Agron. 41 (2): 191-194.

35. Thakaral S, Kadian V, Kumar S (2003) Effect of different organic and fertilizer levels on yield and yield attributes of wheat. Haryana J. Agron. 19(1): 60-62.

36. Yadav D, Kumar A (2009) Long-term effect of nutrient management on soil health and effect of integrated use of organic and inorganic nitrogen sources on wheat yield.

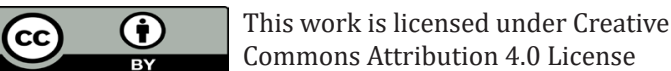

To Submit Your Article Click Here: Submit Article

DOI: $10.32474 /$ CIACR.2020.09.000302

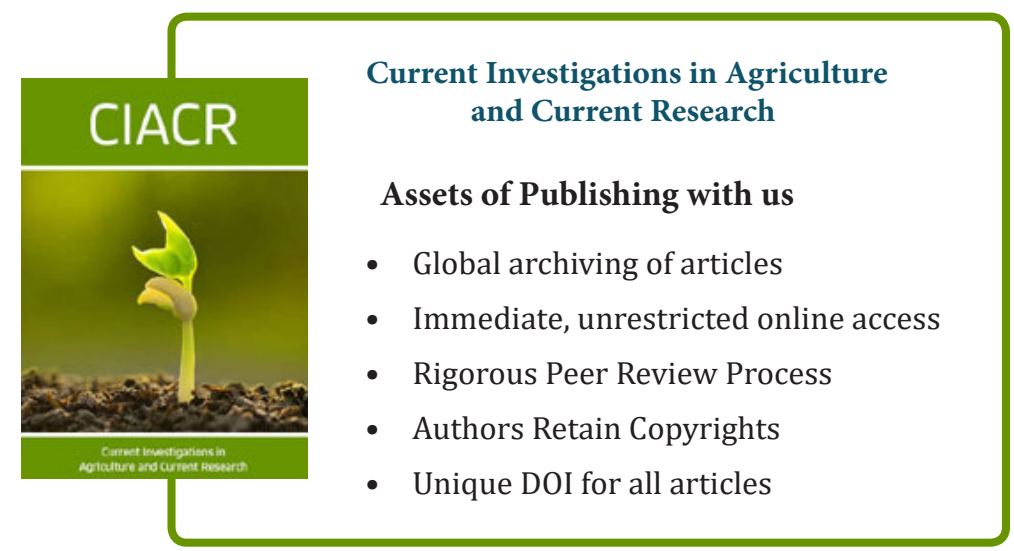

